\title{
Model to assess workload of village doctors in the National Essential Public Health Services Program in six provinces of China
}

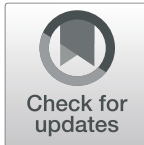

Delu Yin ${ }^{1,2^{*}}$, Tao Yin ${ }^{1}$, Huiming Yang ${ }^{1}$, Lihong Wang ${ }^{1}$ and Bowen Chen ${ }^{1 *}$

\begin{abstract}
Background: No studies, particularly quantitative analyses, have been conducted regarding the workload of village doctors in the National Essential Public Health Services (NEPHS) program and differences in service delivery by village doctors, according to region and services. In this study, we developed a quantitative analysis approach to measure the workload of NEPHS provided by village doctors in six provinces of China in 2016. We aimed to identify areas and services of the NEPHS needing improvement, so as to implement targeted measures to ensure adequate delivery of NEPHSs in rural remote underserved areas.

Methods: Based on survey data from 300 town hospital centers (THCs) located in 60 counties in the six selected provinces, we calculated village doctors' share of workload under the NEPHS using the equivalent value (EV) model. To define the workload and corresponding EV of each NEPHS, a series of five meetings was held with THC managers, public health workers, family physicians, nurses and village doctors. Field observations were conducted to verify the workload and EV of each service.
\end{abstract}

Results: Village doctors' share of the workload under the NEPHS program was $43.71 \%$ across the 300 sampled THCS in six provinces. The village doctors' workload shares for different NEPHS ranged from 17.14 to $57.00 \%$. The percentage workload undertaken by village doctors under the NEPHS program varied across different provinces, with the highest proportion $63.4 \%$ and the lowest $28.5 \%$.

Conclusions: The total NEPHS workload assigned to village doctors by THCs in the six sampled provinces exceeded the Chinese government's requirement of 40\%, but the workload proportion in some provinces was less than 40\%. In addition, the percentage workload for some NEPHS undertaken by village doctors was lower than others. We suggest conducting district-level analysis of the workload among village doctors under the NEPHS program using the EV method, to identify areas and services needing improvement, to implement targeted measures to expand and promote health service provision in China's rural underserved areas.

Keywords: Workload, Village doctors, National Essential Public Health Services program, Equivalent value

\footnotetext{
*Correspondence: deluyin@126.com; 1726137684@qq.com

${ }^{1}$ Capital Institute of Pediatrics, 2 YaBao Road, \#330, ChaoYang District, Beijing 100020, China

Full list of author information is available at the end of the article
}

(c) The Author(s). 2020 Open Access This article is licensed under a Creative Commons Attribution 4.0 International License, which permits use, sharing, adaptation, distribution and reproduction in any medium or format, as long as you give appropriate credit to the original author(s) and the source, provide a link to the Creative Commons licence, and indicate if changes were made. The images or other third party material in this article are included in the article's Creative Commons licence, unless indicated otherwise in a credit line to the material. If material is not included in the article's Creative Commons licence and your intended use is not permitted by statutory regulation or exceeds the permitted use, you will need to obtain permission directly from the copyright holder. To view a copy of this licence, visit http://creativecommons.org/licenses/by/4.0/ The Creative Commons Public Domain Dedication waiver (http://creativecommons.org/publicdomain/zero/1.0/) applies to the data made available in this article, unless otherwise stated in a credit line to the data. 


\section{Background}

Recent decades have witnessed rapid improvement in China's public health system, with average life expectancy up from 71.4 to 74.8 years between 2000 and 2010 $[1,2]$, the maternal mortality rate down from 53.0 to 30.0 per 100,000 population and the infant mortality rate dropping from32.2 to 13.1 per 1000 live births between 2000 and 2010 [3-5]. Despite this progress, diseases including hypertension, obesity, diabetes and other noncommunicable diseases still pose challenges to China's public health $[6,7]$. To tackle these issues and rid patients of unnecessary and costly secondary and tertiary care, early prevention and intervention programs have been in place since 2009. One of these, called the $\mathrm{Na}$ tional Essential Public Health Services (NEPHS) program, is intended to provide equal access to public health services regardless of geographic location and to expand the coverage of essential public health services to all Chinese residents [8]. The NEPHSs are the most essential public health services provided free of charge to all residents, focusing on children, pregnant women, the elderly and patients with chronic diseases, aiming at the main health problems of urban and rural residents. The funds needed to provide these services are mainly borne by the governments. With the economic and social development, changes of public health service needs and financial affordability, the NEPHS items will be adjusted timely [9]. The NEPHS program aims to narrow the gap between rural and urban residents with respect to essential public health services and to ensure equity of access to these services [9]. Since the NEPHS program was launched 10 years ago, the types of services included in this program have progressively increased, from nine in 2009 to 12 in 2016. The allowance standard per capita for the program has increased from 2.38 USD in 2009 to 7.94 USD in 2016. The 12 types of public health services mainly target children aged 0-6 years, pregnant women, those aged over 65 and patients with mental health issues and chronic conditions $[10,11]$. Services are offered through community-based primary health care facilities [9]. These are universally accessible and cover town hospital centers (THCs) and village clinics serving 589.7 million residents in rural areas of China as well as community health service facilities that served 793.0 million residents in urban areas in 2016 [12]. In particular, the NEPHS program in China differs from those outlined by the World Health Organization [13] and by the US Centers for Disease Control and Prevention [14]. China's NEPHS are only provided by primary health care facilities, not the whole public health system. Secondly, the program focuses on essential primary care (maternal, infant and older adult health) accessible for all people, rather than regulatory and monitoring tasks.
Chinese healthcare systems covering both urban and rural residents have been put in place. In the rural areas, it refers to a three-level medical service network that comprises the county hospital, the THCs and village clinics, with the county hospital performing the leading role, and THCs and village clinics service at the base. And in the cities and towns, it refers to a new type of urban medical health service system that features division of responsibilities as well as cooperation among various types of hospitals at all levels and community healthcare centers $[15,16]$. This rural three-tiered system was designed to promote the efficient allocation of health care resources between primary and tertiary care facilities. In the system, county hospitals, THCs, and village clinics differ in scale and functions. Ideally, patients with minor ailments are directed to village doctors in village clinics (primary facilities). Patients with more serious illnesses are transferred to THCs (second-tier or secondary facilities), and only the most seriously ill are sent to county hospitals (third-tier or tertiary facilities) [15]. THCs generally have different numbers of inpatient beds (35.35 on average in 2016 [17]) whereas village clinics have no beds. Chinese rural doctors were originally called "barefoot doctors", born in the 1950s. They referred to the rural medical personnel who were not formally trained in medical treatment, still hold agricultural household registration, and in some cases were "semi agricultural and semi medical" [18]. China implemented the "Regulations on the Administration of Village Doctors" to improve the professional quality of rural doctors on 1 January 2004. Village doctors are now required to finish 2 to 3 years of professional training. Only village doctors who pass the professional training and corresponding examination can obtain the practice certificate [18]. As the basis of health service networks in rural areas, village doctors currently serve nearly half the population of China (42.6\%). Before the start of the NEPHS program, there were 864,000 village doctors working in 583,000 village clinics in 2005. By the end of 2016, 639,000 village clinics had been set up in 560,000 administrative villages across China. In total, there are 1, 436,000 staff members in these village clinics, including 320,000 practicing (assistant) physicians and 933,000 village doctors. The number of consultations provided by village doctors and practicing (assistant) physicians in 2016 reached 1.85 billion, 2.57 times that of consultations provided to urban residents by practitioners working in community health service facilities ( 0.72 billion) [19]. The number of residents served by one village doctor varies with the number of doctors in the village. On average, one village doctor might provide primary health care for 1000-2000 rural residents [19].

It is mandatory for township hospital centers (THCs) and village clinics to provide NEPHS to rural residents 
[20]. Central and local governments are responsible for subsidizing village doctors for providing these services [21]. The willingness of village doctors and THC managers to provide NEPHS is relatively high because of the introduction of a minimum subsidy [12]. The NEPHS program allowance makes up the largest proportion of village doctors' income throughout most of rural China $[12,22]$. In an effort to reasonably distribute the total workload among THCs and village clinics, the government also transfers, in principle, no less than $40 \%$ of the NEPHS workload to village doctors via the program allowance in the form of government service purchases based on performance assessment since 2016 [23]. The central government encourages village doctors to undertake a greater workload in the NEPHS program, to ensure income for village doctors from NEPHS. However, no ideal national workload standard for village doctors in the NEPHS has been developed owing to great differences among rural regions of China [23]. Funds are paid to the THCs and allocated by the THCs to village doctors and THCs. The distribution is based on the estimate of village doctors' performance generally including work volume, quality and residents' satisfaction with NEPHS [12]. THCs might impose an economic penalty on village doctors for work that is poor or unfinished [20, 24].

It is widely accepted that medical and health services in rural China are insufficient. Village doctors have an increasingly important role in the provision of NEPHS in rural China [24, 25]. The government has attached great importance to facilitating the provision of a greater quantity and higher quality of NEPHS by village doctors, which not only helps to improve the accessibility to public health services in rural areas but also stabilizes teams of village doctors $[25,26]$. In recent years, several qualitative studies have been carried out on the provision of NEPHS by village doctors [12, 18, 24-26]. The study findings show that these doctors face many challenges in providing NEPHS and many factors affect the provision of health services. Some factors like village doctors' age, sex (in most districts of China, male village doctors do not provide maternal health services to women), or poor level of education are difficult to change whereas others can be improved, such as lack of effective incentives, poor computer skills, inadequate professional NEPHS training, insufficient equipment allocation and lack of cooperation from rural residents [12, 18]. Identifying areas and services of NEPHS that need improvement, so as to adopt targeted measures to expand these, is conducive to ensuring the adequate delivery of NEPHS in rural remote areas. It is a challenge for primary health managers, some of whom are not medical professionals, to identify weak areas and services within the NEPH program unless simple quantitative methods and tools are used. However, there are no studies, particularly quantitative analyses, on the public health service workload of village doctors and differences in service delivery by village doctors according to region and services. The present analysis can provide a comprehensive perspective on the provision of public health services in rural areas by village doctors. We used a model-based method to calculate the NEPHS workload of village doctors in 300 THCs in 60 counties of six provinces in China. Our findings can provide a reference point and basis for governments at all levels, especially grass-roots health management departments, to identify areas and services of the NEPHS program needing improvement, to implement measures to expand services in underserved areas.

\section{Methods}

\section{Sampling}

In this study, we adopted a random cluster sampling method. Among six sample provinces, two provinces were selected for this survey in the eastern, central and western regions (Eastern: Zhejiang and Fujian; central: Anhui and Henan; western: Yunnan and Shaanxi). In each province, we chose five prefecture-level cities at random and in each prefecture-level city, we randomly selected two counties. Five THCs were randomly chosen from each county. In total, 300 THCs from six provinces were surveyed. On average, each THC has 40 on-duty staff, 34 health care specialists, 16 doctors and 5 certified (assistant) doctors, with an average of 37,270 outpatient and emergency visits plus 1344 inpatients per year. An average of 20 administrative villages and 16 village clinics are under the governance of each THC. Each village clinic is staffed by 1.3 health care professionals.

\section{Data collection}

Using the NEPHS guidelines for 2011, the research team designed questionnaires and survey instructions (see the questionnaire on job responsibilities of village doctors in the supplementary material). Survey questions covered basic information of the sampled THCs and statistics of the total workload assigned according to the 12 types of services and the share of workload undertaken by village doctors in village clinics. The share of workload undertaken by village doctors in village clinics was estimated and reported separately by each service-related department in THCs according to the actual workload carried out by village doctors. The survey tool was pre-tested in two THCs of Beijing and further revised. Before conducting the survey, the research team confirmed the list of sample provinces, cities and counties. To guarantee a high response rate, the Primary Health Department of the National Health and Family Planning Commission issued a notice regarding the survey. Provincial health and family planning administrative departments in the sample provinces organized sample counties and 
selected sample THCs, as required, checking whether all answers on the questionnaires had been completed and reviewing the data for accuracy. After receiving the questionnaires, the research team rechecked everything and carried out logic checks. During the survey, the research team provided advice by telephone and kept records.

\section{Model}

The equivalent value (EV) method has been used to estimate the cost of the NEPHS program and to calculate community health-staffing requirements [27-31]. In the present study, we used the EV method to build a model for measuring the workload of NEPHS provided by village doctors, according to the following steps: 1 ) determine the standard service protocol of all types of NEPH $S$; 2) determine the workload and EV of each NEPHS compared with a standard clinic visit; 3 ) calculate the village doctors' workload in the NEPHS program.

\section{Step 1: determining the standard service protocol} In 2016, the NEPHS program had 12 types of public health services. These included establishing health records for residents; management of patients with chronic non-communicable diseases; physical examination for major diseases in children, women and older people; health education; vaccination services for vaccinepreventable diseases and prevention and control of major infectious diseases. All 12 types of NEPHS are included in the 2011 NEPHS guidelines [11].

\section{Step 2: determining the workload and EV of each NEPHS}

To determine workload (person-time), we used a multistage iterative feedback and revision process [30-32]. Participants $(n=60)$ from the six sampled provinces were invited to attend a series of five meetings according to their expertise with NEPHS. Participants included THC managers $(n=12)$, public health workers $(n=12)$, family physicians $(n=12)$, nurses $(n=12)$ and village doctors $(n=12)$. During the meetings, participants discussed the amount of person-time required for each NEPHS, according to the 2011 NEPHS guidelines. Participants also suggested modifications to the workload indicators. Socioeconomic education levels among villagers as well as population density in western provinces are lower than those in the central and eastern provinces. Participants generally believed that these differences affect the delivery of NEPHS, thus affecting their workload [30-32]. For example, for rural residents in western China, a clinic visit or home visit may require more time from village doctors. Additionally, NEPHS may be provided using mobile medical facilities to assure service accessibility, which will also have an impact on the NEPHS workload. The gap in the workload of NEPH
$\mathrm{S}$ between eastern and central China was relatively small, so these were combined into one region, and two sets of specific workload were created for each NEPHS.

To test the workload of each NEPHS, four research assistants were trained to observe and record the persontime for each type of service in 12 THCs randomly chosen from the six sampled provinces. In terms of services that could not be recorded during direct observation, face-to face interviews with public health workers were conducted to determine their workload. The person-time for each NEPHS was rechecked and modified on the basis of direct observation and interviews.

To ensure that different public health services could be compared directly, a "standard clinic visit" was introduced as a benchmark to gauge the EV for NEPHS [27-32]. A standard clinic visit referred to a family physician consulting with one patient for $15 \mathrm{~min}$ [33] and the EV of a standard clinic visit was defined as 1 . The EV of each NEPHS was then determined based on the person-time compared with a standard clinic visit. The workload and EV of each NEPHS in different areas was defined separately and is shown in Table 1.

\section{Step 3: calculate village doctors' workload in the NEPHS program}

Based on the EV of each NEPHS, the workload undertaken by village doctors under the NEPHS program was calculated using the following process:

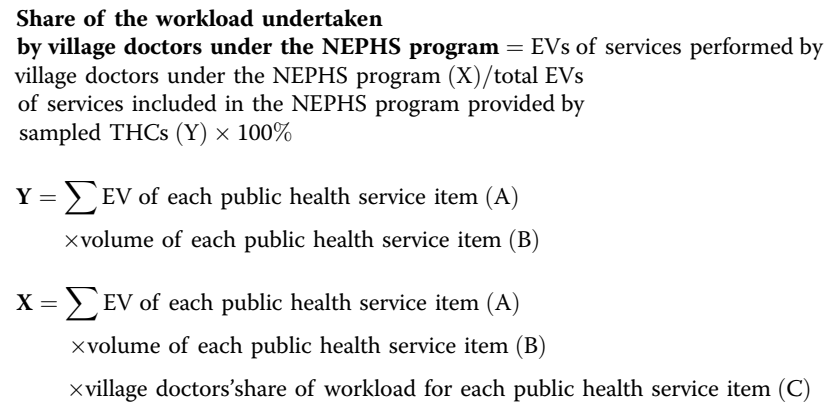

A: sourced from the EV of each NEPHS in the Table 1;

B: sourced from surveys on the total workload assigned according to the 12 types of service (see section 2.2, Data Collection);

C: sourced from surveys regarding the share of workload undertaken by village doctors in village clinics. This was estimated and reported separately by each servicerelated department of THCs according to the actual workload conducted by village doctors (see the Data Collection section).

\section{Results}

Workload for different NEPHS provided by village doctors The total workload of NEPHS was 42.32 million EVs across 300 sample THCs from six provinces; village 
Table 1 Workload and EV of each NEPHS in different areas (compared with a standard clinic visit)

\begin{tabular}{|c|c|c|c|c|c|c|}
\hline \multirow[t]{2}{*}{ Types } & \multirow[t]{2}{*}{ Service Contents } & \multirow[t]{2}{*}{ Unit } & \multicolumn{2}{|c|}{ Mid-east China $^{a}$} & \multicolumn{2}{|c|}{ Western China } \\
\hline & & & $\begin{array}{l}\text { Workload } \\
\text { (minutes) }\end{array}$ & Mean EV & $\begin{array}{l}\text { Workload } \\
\text { (minutes) }\end{array}$ & $\overline{\text { Mean EV }}$ \\
\hline Standard clinic visit & Family physician consulting with patient & per person & 15.0 & 1.0 & 15.0 & 1.0 \\
\hline \multirow{2}{*}{$\begin{array}{l}\text { Health records management } \\
\text { service }\end{array}$} & Establish residents' health records & per person & 30.0 & 2.0 & 37.5 & 2.5 \\
\hline & Update of residents' health records & per person & 7.5 & 0.5 & 12.0 & 0.8 \\
\hline \multirow[t]{4}{*}{ Health education } & $\begin{array}{l}\text { Make annual implementation plan of } \\
\text { health education }\end{array}$ & per time & 720.0 & 48.0 & 1170.0 & 78.0 \\
\hline & Set up health education bulletin board & per time & 373.5 & 24.9 & 720.0 & 48.0 \\
\hline & Public health consultation activities & per time & 669.0 & 44.6 & 135.0 & 9.0 \\
\hline & Public health knowledge lecture & per time & 463.5 & 30.9 & 480.0 & 32.0 \\
\hline \multirow[t]{3}{*}{ Immunizations } & Establish vaccination file & per person & 9.0 & 0.6 & 10.5 & 0.7 \\
\hline & Vaccination service & per visit & 16.5 & 1.1 & 16.5 & 1.1 \\
\hline & $\begin{array}{l}\text { Handling of suspected abnormal } \\
\text { vaccination reaction }\end{array}$ & per visit & 18.0 & 1.2 & 6.0 & 0.4 \\
\hline \multirow{4}{*}{$\begin{array}{l}\text { Health services for children } \\
\text { aged } 0 \text { to } 6 \text { years }\end{array}$} & Family visit of newborn & per visit & 118.5 & 7.9 & 52.5 & 3.5 \\
\hline & 42 days follow-up & per visit & 72.0 & 4.8 & 51.0 & 3.4 \\
\hline & Infant physical examination & per visit & 30.0 & 2.0 & 16.5 & 1.1 \\
\hline & $\begin{array}{l}\text { Physical examination of preschool } \\
\text { children }\end{array}$ & per visit & 30.0 & 2.0 & 69.0 & 4.6 \\
\hline \multirow[t]{5}{*}{ Maternal health services } & Early pregnancy health management & per visit & 54.0 & 3.6 & 37.5 & 2.5 \\
\hline & $\begin{array}{l}\text { Health management in the second } \\
\text { trimester }\end{array}$ & per visit & 40.5 & 2.7 & 27.0 & 1.8 \\
\hline & Health management in late pregnancy & per visit & 42.0 & 2.8 & 27.0 & 1.8 \\
\hline & Postpartum visit & per visit & 81.0 & 5.4 & 30.0 & 2.0 \\
\hline & 42 days postpartum health examination & per visit & 42.0 & 2.8 & 28.5 & 1.9 \\
\hline \multirow[t]{2}{*}{ Elderly people's health services } & Physical examination for the elderly & per person & 39.0 & 2.6 & 34.5 & 2.3 \\
\hline & Health guidance for the elderly & per person & 12.0 & 0.8 & 6.0 & 0.4 \\
\hline \multirow{3}{*}{$\begin{array}{l}\text { Health services for patients } \\
\text { with hypertension }\end{array}$} & Screening of patients with hypertension & per person & 39.0 & 2.6 & 24.0 & 1.6 \\
\hline & $\begin{array}{l}\text { Follow up evaluation and classified } \\
\text { intervention of hypertension patients }\end{array}$ & per visit & 36.0 & 2.4 & 36.0 & 2.4 \\
\hline & $\begin{array}{l}\text { Health examination for patients with } \\
\text { hypertension }\end{array}$ & per person & 42.0 & 2.8 & 34.5 & 2.3 \\
\hline \multirow{3}{*}{$\begin{array}{l}\text { Health services for patients } \\
\text { with type II diabetes }\end{array}$} & Diabetes screening & per person & 42.0 & 2.8 & 31.5 & 2.1 \\
\hline & $\begin{array}{l}\text { Follow up evaluation and classified } \\
\text { intervention of diabetic patients }\end{array}$ & per visit & 36.0 & 2.4 & 37.5 & 2.5 \\
\hline & $\begin{array}{l}\text { Physical examination of diabetic } \\
\text { patients }\end{array}$ & per person & 42.0 & 2.8 & 37.5 & 2.5 \\
\hline \multirow[t]{3}{*}{$\begin{array}{l}\text { Health services for patients with } \\
\text { severe mental illness }\end{array}$} & $\begin{array}{l}\text { Information management of patients } \\
\text { with severe mental illness }\end{array}$ & per person & 108.0 & 7.2 & 79.5 & 5.3 \\
\hline & $\begin{array}{l}\text { Follow up evaluation and classified } \\
\text { intervention of severe mental illness }\end{array}$ & per visit & 72.0 & 4.8 & 42.0 & 2.8 \\
\hline & $\begin{array}{l}\text { Physical examination for severe } \\
\text { mental illness }\end{array}$ & per person & 66.0 & 4.4 & 43.5 & 2.9 \\
\hline \multirow{2}{*}{$\begin{array}{l}\text { Reporting and management of } \\
\text { infectious diseases and public } \\
\text { health emergencies }\end{array}$} & $\begin{array}{l}\text { Discovery and registration of infectious } \\
\text { diseases and public health emergencies }\end{array}$ & per time & 114 & 7.6 & 21.0 & 1.4 \\
\hline & $\begin{array}{l}\text { Report and handling report of infectious } \\
\text { diseases and public health emergencies }\end{array}$ & per time & 121.5 & 8.1 & 7.5 & 0.5 \\
\hline $\begin{array}{l}\text { Health management with } \\
\text { Chinese medicine }\end{array}$ & $\begin{array}{l}\text { Recognition of TCM constitution } \\
\text { (aged over 65) }\end{array}$ & per visit & 30.0 & 2.0 & 27.0 & 1.8 \\
\hline
\end{tabular}


Table 1 Workload and EV of each NEPHS in different areas (compared with a standard clinic visit) (Continued)

\begin{tabular}{|c|c|c|c|c|c|c|}
\hline \multirow[t]{2}{*}{ Types } & \multirow[t]{2}{*}{ Service Contents } & \multirow[t]{2}{*}{ Unit } & \multicolumn{2}{|c|}{ Mid-east China $^{a}$} & \multicolumn{2}{|c|}{ Western China } \\
\hline & & & $\begin{array}{l}\text { Workload } \\
\text { (minutes) }\end{array}$ & Mean EV & $\begin{array}{l}\text { Workload } \\
\text { (minutes) }\end{array}$ & Mean EV \\
\hline & $\begin{array}{l}\text { Health care guidance of traditional } \\
\text { Chinese medicine (over } 65 \text { years old) }\end{array}$ & per visit & 15.0 & 1.0 & 13.5 & 0.9 \\
\hline & $\begin{array}{l}\text { Chinese medicine health guidance for } \\
\text { children }(6,12,18,24,30,36 \text { months old })\end{array}$ & per visit & 24.0 & 1.6 & 21.0 & 1.4 \\
\hline \multirow[t]{4}{*}{$\begin{array}{l}\text { Health supervision assistance } \\
\text { services }\end{array}$} & $\begin{array}{l}\text { Food safety information report of health } \\
\text { supervision }\end{array}$ & per time & 565.5 & 37.7 & 495.0 & 33.0 \\
\hline & Occupational health consultation guidance & per time & 205.5 & 13.7 & 180.0 & 12.0 \\
\hline & $\begin{array}{l}\text { Health supervision assists in the inspection } \\
\text { of drinking water health and safety }\end{array}$ & per time & 514.5 & 34.3 & 517.5 & 34.5 \\
\hline & $\begin{array}{l}\text { Health supervision and coordination of } \\
\text { school health services }\end{array}$ & per time & 171.0 & 11.4 & 90.0 & 6.0 \\
\hline
\end{tabular}

Abbreviations: NEPHSP National Essential Public Health Services program, EV equivalent value, TCM traditional Chinese medicine

a The gap in the NEPHS EV between eastern and central China was relatively small, so these are combined into one region in the table

doctors carried out $43.71 \%$ of the total workload under the NEPHS program in 2016. The workload share of different NEPHS undertaken by village doctors ranged from 17.10 to $57.00 \%$; the workload share was more than $50.00 \%$ of health services for patients with hypertension, type II diabetes and severe mental illness whereas it was relatively lower for other services including reporting and management of infectious diseases and public health emergencies, health supervision assistance services and immunizations (Table 2).

\section{Percentage workload of different NEPHS provided by village doctors in different provinces}

Our comparative analysis showed that the percentage workload undertaken by village doctors under the NEPH $\mathrm{S}$ program varied among different provinces, with the highest proportion $63.4 \%$ and the lowest $28.5 \%$. The workload share for different types of public health services provided by village doctors also varied in different provinces (Table 3). To make some proposals regarding the reasons underlying this variation, the number of village clinics, health workers, and village doctors in the six provinces were compared [17]. Preliminary comparative analysis showed that provinces with a higher average number of health workers per village clinic (provinces 4 and 6) had a higher proportion of the NEPHS workload carried by village doctors.

\section{Discussion}

In this study, we carried out quantitative analysis of the workload of village doctors under the NEPHS program and calculated the share of the total workload among these doctors. Our results showed that $43.71 \%$ of the total NEPHS workload was assigned to village doctors by THCs in the six sampled provinces, exceeding the Chinese government's requirement of $40 \%$. There were differences in the percentage NEPHS workload undertaken by village doctors among different provinces and according to different types of service. The reasons for these differences are unclear and require further research. However, previous studies have shown that shortages and aging of village doctors are two of the main barriers to providing public health services among village doctors. Insufficient training and shortages of necessary medical equipment also restrict village doctors' ability to provide additional services [18, 24]. Moreover, establishment of unreasonable performance indicators by THCs and unbalanced allowance quotas has largely affected the enthusiasm of village doctors to provide these services [12, 18]. Consequently, differences among the six sampled provinces may be attributed to the number and capabilities of village doctors, performance indicators, allowance quotas for village doctors and other unknown factors [12, 24, 25]. The workload undertaken by village doctors in the NEPHS program varies according to type of service, which may be related to village doctors' age, sex, computer skills and the number of nurses and administrative staff available to support village doctors [18].In this study, preliminary comparative analysis showed that the percentage workload undertaken by village doctors may be affected not only by the number of village doctors but also the number of other health workers in clinics, such as nurses, because these health workers can undertake some NEPHS tasks.

The present results generate some possible directions for policy adjustment. It is vital to further strengthen the important role of village doctors in providing NEPHS, to guarantee the availability of these services in rural areas. This study showed that differences exist in the percentage of the NEPHS workload taken on by village doctors according to different provinces and different services, with the percentage workload in some provinces lower than $40 \%$. In terms of the types of services and provinces with a lower share of the workload, governments should 
Table 2 Workload of different NEPHS provided by village doctors (2016)

\begin{tabular}{llll}
\hline Types of essential public health services & $\begin{array}{l}\text { Total EVs undertaken by } \\
\text { sampled THCs (One Millions) }\end{array}$ & $\begin{array}{l}\text { EVs Undertaken by village } \\
\text { doctors (One Millions) }\end{array}$ & $\begin{array}{l}\text { Share of workload undertaken } \\
\text { by village doctors (\%) }\end{array}$ \\
\hline Health records management service & 6.59 & 3.27 & 49.54 \\
Health education & 7.13 & 3.37 & 47.24 \\
Immunizations & 3.86 & 1.10 & 28.42 \\
Health services for children aged 0 to 6years & 6.03 & 1.86 & 30.91 \\
Maternal health services & 1.40 & 0.45 & 31.83 \\
Elderly people's health services & 4.27 & 1.78 & 41.80 \\
Health services for patients with hypertension & 7.35 & 4.19 & 57.00 \\
Health services for patients with type II diabetes & 1.98 & 1.10 & 55.42 \\
Health services for patients with severe mental & 0.68 & 0.35 & 51.76 \\
illness & & & 17.14 \\
Reporting and management of infectious diseases & 0.12 & 0.02 & 38.43 \\
and public health emergencies & 2.08 & 0.80 & 26.20 \\
Health management with Chinese medicine & 0.84 & 0.22 & 43.71 \\
Health supervision assistance services & 42.32 & 18.50 & \\
Total & & & \\
\hline
\end{tabular}

Abbreviations: NEPHS National Essential Public Health Services, EV equivalent value, THC town hospital center

focus on those factors can be changed and take appropriate steps, including improving professional skills among village doctors by intensifying professional training, equipping village doctors with the necessary medical facilities and equipment and encouraging them to undertake more work under the NEPHS program by improving performance evaluation and granting a higher program allowance $[12,18]$. The EV method is simple and easy, such that primary health management departments can identify weak areas and services by collecting general data to input in the model. This provides a reference point and basis for identifying areas and services of the NEPHS program needing improvement, so that measures to expand services in underserved areas can be implemented. Therefore, to tackle the question of whether the current workforce can adequately deliver NEPHS in rural areas, it is suggested that government at all levels, especially grass-roots health management departments, adopt the EV method to identify priority areas and services in rural regions, by estimating the proportion administered by village doctors. In addition, the EV method can be used to measure the role of village doctors in providing all primary health services as a whole, so as to target measures for expanding services and

Table 3 Percentage workload undertaken by village doctors in different provinces (2016), NEPHSP

\begin{tabular}{|c|c|c|c|c|c|c|}
\hline Types of essential public health services & Province1 & Province2 & Province 3 & Province4 & Province5 & Province6 \\
\hline Health records management service & 26.6 & 48.1 & 34.9 & 78.0 & 52.6 & 49.4 \\
\hline Health education & 35.3 & 45.6 & 28.0 & 59.6 & 47.2 & 64.2 \\
\hline Immunizations & 34.4 & 23.1 & 21.6 & 26.6 & 27.8 & 33.5 \\
\hline Health services for children aged 0 to 6 years & 27.6 & 28.9 & 37.5 & 30.2 & 30.9 & 30.0 \\
\hline Maternal health services & 29.7 & 34.2 & 37.9 & 27.6 & 24.1 & 36.1 \\
\hline Elderly people's health services & 44.5 & 42.8 & 32.1 & 48.0 & 46.3 & 39.9 \\
\hline Health services for patients with hypertension & 53.4 & 64.2 & 60.5 & 59.0 & 55.3 & 49.8 \\
\hline Health services for patients with type II diabetes & 48.1 & 55.0 & 57.2 & 53.1 & 55.6 & 62.0 \\
\hline Health services for patients with severe mental illness & 55.8 & 46.5 & 51.3 & 48.1 & 53.8 & 54.6 \\
\hline $\begin{array}{l}\text { Reporting and management of infectious diseases and public health } \\
\text { emergencies }\end{array}$ & 17.9 & 18.8 & 14.3 & 18.6 & 22.6 & 13.2 \\
\hline Health management with Chinese medicine & 40.0 & 34.0 & 39.3 & 36.7 & 41.5 & 38.6 \\
\hline Health supervision assistance services & 19.1 & 41.6 & 21.3 & 17.8 & 18.6 & 41.0 \\
\hline Total & 35.5 & 45.5 & 28.5 & 59.2 & 47.1 & 63.4 \\
\hline
\end{tabular}

Abbreviations: NEPHSP National Essential Public Health Services program 
improve the role of village doctors as health gatekeepers in rural remote areas.

This study is the first in China to calculate the workload proportion of village doctors in the NEPHS program. In recent years, relevant documents issued by the government continue to emphasize the basic requirement of $40 \%$ [23]. The proportion exceeding the service capacity of village doctors is unfavorable to the stability of these doctors as well as to service provision. We should note that China's policy of public health service equalization means that the workload among village doctors is increasing [24]. We must ensure that the workload assigned to these doctors is manageable, based on their individual capabilities [34]. Workloads should not be blindly increased, to avoid undermining rural residents' access to quality public health services $[20,35$, 36]. In our study, the percentage workload undertaken by village doctors in two provinces was more than $60 \%$. We therefore suggest that local governments monitor village doctors' workload in the NEPHS program using the model developed in this study.

Previous studies have shown that THCs and village doctors have different opinions regarding the workload share and job responsibilities allocated to doctors [37, 38]. The measurement in this study may underestimate the workload of village doctors in the NEPHS program. Therefore, a limitation of this research is that we did not investigate workloads from the perspective of doctors in the village clinics themselves. In future, calculations and comparative analyses should be conducted from the perspective of village doctors working in the NEPHS program.

\section{Conclusions}

It is vital for primary health managers to identify areas and services of the NEPHS program that require improvement and to adopt targeted measures to expand these, so as to ensure the adequate delivery of NEPHS in rural remote areas. However, no studies or quantitative analyses to date have investigated the workload of village doctors in the NEPHS program and differences in service delivery by village doctors according to region and services. In this study, we used a quantitative analysis approach and found that $43.71 \%$ of the total NEPHS workload was assigned to village doctors by THCs in six sampled provinces, exceeding the Chinese government's requirement of $40 \%$. Differences exist in the percentage of the NEPHS workload undertaken by village doctors among different provinces and services, with the workload proportion in some provinces less than $40 \%$.We suggest conducting district-level analysis of the workload among village doctors under the NEPHS program using the EV method in China's rural underserved areas, to identify areas and services of the NEPHS program that require improvement and implement targeted measures to promote health service provision. The present model based on EV of the NEPHS could be used to monitor village doctors' workload under the NEPHS program as well to ensure that the workload assigned to village doctors is manageable.

\section{Supplementary Information}

The online version contains supplementary material available at https://doi. org/10.1186/s12913-020-05992-y.

Additional file 1. Questionnaire on workload of village doctors in the National Essential Public Health Services Program (NEPHSP).

\section{Abbreviations}

NEPHSP: National Essential Public Health Services Program; THC: Township Hospital Centers; EV: Equivalent value

\section{Acknowledgments}

We would like to thank the Primary Health Care Division, National Health and Family Planning Commission, for their generous support. We also thank Liwen Bianji, Edanz Group China (www.liwenbianji.cn/ac), for editing the English text of a draft of this manuscript.

\section{Authors' contributions}

$Y D, Y T, Y H, W L$ and $C B$ were responsible for the conception, design and acquisition of data. YD was responsible for analysis and interpretation of the data and drafting the initial manuscript. YT critically revised the manuscript for important intellectual content. CB was responsible for reviewing all drafts of the manuscript and giving final approval for the version to be published. All authors read and approved the final manuscript.

\section{Funding}

This work was funded by Natural Science Foundation of China (71673191). The funder provided financial support and had no role in study design, data collection and analysis, decision to publish, or preparation of the manuscript.

Availability of data and materials

Questionnaire on the job responsibilities of village doctors is provided as Supplementary file 1.

\section{Ethics approval and consent to participate}

The study protocol was approved by the Institutional Review Board of the Capital Institute of Pediatrics, Beijing, China (SHERLL number 2016015). Each participant provided their written consent prior to data collection.

Consent for publication

Not applicable.

\section{Competing interests}

The authors declare that they have no competing interests.

\section{Author details}

${ }^{1}$ Capital Institute of Pediatrics, 2 YaBao Road, \#330, ChaoYang District, Beijing 100020, China. ${ }^{2}$ Community Health Association of China, 2 YaBao Road, \#330, ChaoYang District, Beijing 100020, China.

Received: 26 March 2020 Accepted: 2 December 2020

Published online: 09 December 2020

\section{References}

1. Meng Q, Tang S. Universal Coverage of Health Care in China: Challenges and Opportunities. World Health Report (2010) Background Paper, No 7 2010. https://doi.org/10.1016/j.sbspro.2013.03.091.

2. China Statistical Yearbooks 2011. Available online: http://www.stats.gov.cn/ tjsj/ndsj/2011/indexch.htm (Accessed on 29 Apr 2001). 
3. Statistical bulletin of health development in China in 2000. Available online: http://www.nhc.gov.cn/mohwsbwstjxxzx/57967/200805/34847.shtml (Accessed on 26 Apr 2002).

4. Statistical bulletin of health development in China in 2010. Available online: http://www.nhc.gov.cn/mohwsbwstjxxzx/s7967/201104/51512.shtml.html (Accessed on 15 Aug 2011).

5. Statistical bulletin of health development in China in 2011. Available online: http://www.nhc.gov.cn/mohwsbwstjxxzx/s7967/201204/54532.shtml (Accessed on 20 Apr 2012).

6. The fourth national health services survey report. Available online: http:// www.nhc.gov.cn/mohwsbwstjxxzx/s8211/201009/49165.shtml (Accessed on 21 Sept 2010).

7. Yang G, Kong L, Zhao W, Wan X, Zhai Y, Chen LC, Koplan JP. Emergence of chronic non-communicable diseases in China. Lancet. 2008;372(9650):1697705. https://doi.org/10.1016/S0140-6736(08)61366-5.

8. Guidelines for Deepening Health Systems Reform. Available online: http:// www.gov.cn/gongbao/content/2009/content_1284372.htm (Accessed on 17 Mar 2009).

9. Opinion on promoting gradual equalization of the essential public health services. Available online: http://www.gov.cn/ztzl/ygzt/content_1661065.htm (Accessed on 22 July 2010).

10. Guideline of National Essential Public Health Services (2009 version). Available online: http://www.nhc.gov.cn/jws/s3581r/200910/fe1 cdd87dcfa4622abca696c712d77e8.shtml?from=singlemessage (Accessed on 16 Oct 2009).

11. Guideline of National Essential Public Health Services (2011 version). Available online: http://www.nhc.gov.cn/zwgk/wtwj/201304/cb5978bb42 814451a26e5c97dd855254.shtml (Accessed on 24 May 2011).

12. Ding $Y$, Smith HJ, Fei $Y, X u B$, Nie $S$, Yan W, et al. Factors influencing the provision of public health services by village doctors in Hubei and Jiangxi provinces, China. Bull World Health Organ. 2013;91:64-9. https://doi.org/10. 2471/BLT.12.109447.

13. The 10 Essential Public Health Operations. Available online: https://www. euro.who.int/en/health-topics/Health-systems/public-health-services/policy/ the-10-essential-public-health-operations.

14. 10 Essential Public Health Services. Available online: https://www.cdc.gov/ publichealthgateway/publichealthservices/essentialhealthservices.html.

15. Meng Q, Yuan J, Jing L, Zhang J. Mobility of primary health care workers in China. Hum Resour Health. 2009;7:24. https:/doi.org/10.1186/1478-4491-7-24.

16. Medical and Health Services in China. Available online: http://en.nhc.gov. cn/2012-12/27/c_75638.htm. (Accessed on 27 Dec 2012).

17. Statistical bulletin of health development in China in 2016. Available online: http://www.nhc.gov.cn/guihuaxxs/s10748/201708/d82fa7141696407abb4 ef764f3edf095.shtml. (Accessed on 18 Aug 2017).

18. Wang $\mathrm{Q}$, et al. What are the challenges faced by village doctors in provision of basic public health Services in Shandong, China? A qualitative study. Int J Environ Res Public Health. 2019;16(14):2519. https://doi.org/10.3390/ ijerph16142519.

19. Statistical bulletin of health development in China in 2017. Available online: http://www.nhc.gov.cn/guihuaxxs/s10743/201806/44e3cdfe11fa4c7f92 8c879d435b6a18.shtml (Accessed on 12 June 2018).

20. Zhang S, Zhang W, Zhou H, et al. How China's new health reform influences village doctors' income structure: evidence from a qualitative study in six counties in China. Hum Resour Health. 2015;13:26. https://doi. org/10.1186/s12960-015-0019-1.

21. State Council of the People's Republic of China. Regulation on the practicing of village doctors. Beijing: SCPRC; 2004. [Chinese]. Available from: http://www.gov.cn/banshi/2005-08/02/content_19251.htm (Accessed 2 May 2012).

22. Hu D, Zhu W, Fu Y, et al. Development of village doctors in China: financial compensation and health system support. Int J Equity Health. 2017;16(1):9. https://doi.org/10.1186/s12939-016-0505-7.

23. Notice on the provision of the National Essential Public Health Services in 2016. Available online: http://www.nhc.gov.cn/jws/s3577/201606/f29a465 9c7f4455ca6f62f8d14eb4b02.shtml (Accessed on 28 June 2016).

24. Li T, Lei T, Xie Z, et al. Determinants of basic public health services provision by village doctors in China: using non-communicable diseases management as an example. BMC Health Serv Res. 2015;16:42. https://doi. org/10.1186/s12913-016-1276-y.

25. Li X, Cochran C, Lu J, et al. Understanding the shortage of village doctors in China and solutions under the policy of basic public health service equalization: evidence from Changzhou. Int J Health Plann Manage. 2015; 30(1):42-55. https://doi.org/10.1002/hpm.2258.

26. Zhou H, Zhang W, Zhang S, et al. Health providers' perspectives on delivering public health services under the contract service policy in rural China: evidence from Xinjian County. BMC Health Serv Res. 2015;15:75. https://doi.org/10.1186/s12913-015-0739-X.

27. Yang $H$, Yin D, Zhao J, Li N, Yin T, Zheng X, Shi Y, Xu Q, Wang L, Xin Q, Li R, Xiao F, Chen B. Workload Evaluation Model of Community Health Facilities in Xicheng District, Beijing. Chin Gen Pract. 2015;7:751-4. https://doi.org/10. 3969/j.issn. 1007-9572.2015.07.006.

28. Chen B, Yin D, Cheng W, et al. Discussion on cost estimation model of community health service. Chin Health Econ. 2015;34(1):40-1. https://doi. org/10.7664/CHE20150111.

29. Yin $\mathrm{D}$, Chen $B$, Cheng $W$, et al. Constructing the cost estimation model for community health service items in Beijing. Chin Health Econ. 2015;34(1):424. https://doi.org/10.7664/CHE20150112..

30. Delu Y, Wong ST, Chen W, et al. A model to estimate the cost of the National Essential Public Health Services Package in Beijing, China. BMC Health Serv Res. 2015;15:222. https://doi.org/10.1186/s12913-015-0902-4.

31. Yin $\mathrm{D}$, Yin $\mathrm{T}$, Yang $\mathrm{H}$, Xin $\mathrm{Q}$, et al. An economic-research-based approach to calculate community health-staffing requirements in Xicheng District, Beijing. Hum Resour Health. 2016;14:70. https://doi.org/10.1186/s12960-0160152-5.

32. Yin $D$, Hua $B$, Zhang $D$, et al. Practical model of performance evaluation of primary health care services institutions based on relative value quantitative standards. Chin J Health Policy. 2019;12(1):55-9. https://doi.org/10.3969/j. issn. 1674-2982.2019.01.008.

33. General practitioner standardization training outline (on trial). Available online: http://www.nhc.gov.cn/qjjys/s7945/201904/f0359ac60f714d5a82575 a2f2155286a.shtml (Accessed on 2 Apr 2019).

34. Yang L, Cui Y, Han H, et al. A study on the responsibility division and allocation of funds under the national basic public health service program in township-level and village-level medical institutions. Chin J Women Child Health. 2011;2(2):51-4. https://doi.org/10.19757/j.cnki.issn1674-7763.2011.02.001.

35. Wang $S$, Zhou D, Wang $X$, et al. A study on the county doctors' satisfaction on the collaboration of national primary public health service project and its influencing factors. Chin Health Serv Manage. 2014;31(9):691-3.

36. Tongyu H. A review on how to better implement National Essential Public Health Services Program in China and thoughts on how to perfect policies during "the 13th five-year plan". Chin J Health Policy. 2015;7:43-8. https:// doi.org/10.3969/j.issn.1674-2982.2015.07.007.

37. Liu Y, Ma C, Xiang Y, et al. Analysis on the present responsibility division for township-level and village-level health care institutions in national essential public health service project. Chin Health Econ. 2013;32(9):72-5. https://doi. org/10.7664/CHE20130921.

38. Fang $H$, Zhou $D$, Wang $M$, et al. Responsibility division for health service institutions at township and village level in national basic public health service project. Chin J Public Health. 2015;31(4):405-8. https://doi.org/10, 11847/zgggws2015-31-04-06.

\section{Publisher's Note}

Springer Nature remains neutral with regard to jurisdictional claims in published maps and institutional affiliations.

Ready to submit your research? Choose BMC and benefit from:

- fast, convenient online submission

- thorough peer review by experienced researchers in your field

- rapid publication on acceptance

- support for research data, including large and complex data types

- gold Open Access which fosters wider collaboration and increased citations

- maximum visibility for your research: over $100 \mathrm{M}$ website views per year

At $\mathrm{BMC}$, research is always in progress.

Learn more biomedcentral.com/submissions 